\title{
WSPIERANIE KONKURENCYJNOŚCI POLSKIEGO PRZEMYSŁU W ŚWIETLE ZAŁOŻEŃ NOWEJ POLITYKI PRZEMYSŁOWEJ
}

\author{
Beata Ślusarczyk \\ Politechnika Częstochowska \\ Wydział Zarządzania
}

\begin{abstract}
Streszczenie: Prowadzone w ostatnim czasie publiczne debaty gospodarcze coraz częściej podejmują postulat wdrożenia nowej polityki przemysłowej dla podźwignięcia gospodarek po światowym kryzysie. Niniejszy artykuł podejmuje wskazaną tematykę, przedstawiając genezę obecnego zainteresowania polityką przemysłową. Przeprowadzona analiza szeregu wskaźników ekonomicznych, opartych na wynikach osiągniętych przez przemysł unijny, jak i w poszczególnych krajach UE potwierdza konieczność aplikacji założeń nowej polityki przemysłowej, dla zwiększenia konkurencyjności przemysłu unijnego na tle gospodarki światowej.
\end{abstract}

Słowa kluczowe: polityka przemysłowa, światowy kryzys finansowy, przemysł unijny, przemysł polski

DOI: 10.17512/znpcz.2016.2.01

\section{Wprowadzenie}

W ostatnim czasie w publicznych debatach gospodarczych czy publicystycznych coraz częściej pojawia się postulat wdrożenia nowej polityki przemysłowej, w celu podźwignięcia gospodarek po światowym kryzysie. Szczególnie interesujące i ożywione dyskusje toczą się m.in. na łamach tygodnika „Polityka” (por. Bendyk 2014, s. 64-66; Woś 2015, s. 48-51; Grzeszak 2015, s. 40-43; Karpiński 2015, s. 44-45), gdzie autorzy opracowań wymieniają opinie na temat stanu światowego przemysłu (zwłaszcza polskiego), potrzeby reindustrializacji, wreszcie konieczności uwzględnienia w polityce gospodarczej wspólnot, jak i poszczególnych krajów odpowiednej strategii właśnie dla przemysłu. Niniejszy artykuł podejmuje tę tematykę: przedstawia genezę obecnego zainteresowania tym zagadnieniem; definiuje i krótko charakteryzuje politykę przemysłową, a także prezentuje założenia polityki unijnej w badanym obszarze. Jako że tytuł opracowania wskazuje na potrzebę pochylenia się nad konkurencyjnością polskiego przemysłu, w artykule zaprezentowano dane liczbowe świadczące o jego stanie na tle wybranych krajów europejskich, konkludując - w jakich, kluczowych z punktu widzenia unijnej polityki przemysłowej, obszarach ma jeszcze spore zaległości do nadrobienia.

Celem artykułu jest wyróżnienie potrzeb realizacji nowej polityki przemysłowej w procesie odbudowy gospodarek objętych recesją po kryzysie finansowym z 2008 roku oraz zwiększenia konkurencyjności przemysłu unijnego, ze szczególnym 
uwzględnieniem gospodarki polskiej. Potwierdza to przeprowadzona analiza szeregu wskaźników ekonomicznych, opartych na wynikach osiągniętych przez przemysł unijny, jak i w poszczególnych krajach UE. Istotnym elementem rozważań jest również prezentacja kluczowych założeń i zadań zdefiniowanej w nowy sposób polityki, dedykowanej wspieraniu działalności przemysłowej.

\section{Kryzys gospodarczy przesłanką ponownego zainteresowania polityką przemysłową}

Przez ostatnie kilkanaście lat polityka przemysłowa kojarzyła się jedynie $\mathrm{z}$ anachronizmem, któremu nie należy poświęcać szczególnej uwagi. Przeważało przekonanie, że rozwój gospodarczy osiągnąć można jedynie poprzez rozwój sektora usług i sektora finansów, przy jednoczesnym zmniejszaniu roli przemysłu. Dopiero kryzys zapoczątkowany w USA w 2008 roku unaocznił brak zasadności takiego podejścia. Okazało się, że spekulacje dokonywane na rynkach finansowych doprowadzić mogą do załamania gospodarki nie tylko jednego kraju, ale w wyniku postępującej globalizacji - gospodarek państw całego świata. Ostatnie lata pokazały, że najlepszą drogą wyjścia z kryzysu jest ponowne zwrócenie się w kierunku przemysłu. Jak podkreśla R. Woś, to industrializacja była ważnym fundamentem powojennego sukcesu zachodnich gospodarek, również sektor przemysłowy, nie zaś usługi, generuje najwięcej innowacji technologicznych. Powołując się także na autorytety w dziedzinie ekonomii, jakimi są M. Kondratiew czy J. Schumpeter, pisze, że: „To przemysł stanowi serce kapitalizmu. To stąd wychodzą impulsy dla pozostałej części gospodarki. W tym dla usług, których jest w PKB więcej, ale które jakby żerują na realnym produkcie stworzonym przez twardą gospodarkę" (Woś 2015, s. 49). Kryzys z 2008 roku zmienił tym samym postrzeganie roli przemysłu $\mathrm{w}$ gospodarce. Produkcja przemysłowa odzyskała swoje miejsce w tym znaczeniu, że stosunkowo duży sektor produkcyjny nie jest już uważany za odzwierciedlenie nieefektywnej struktury gospodarczej, nieadekwatnej do postindustrialnego, zdominowanego przez usługi kręgu krajów wysoko rozwiniętych. Obserwacja życia gospodarczego jasno wskazuje, że kraje, które utrzymały większy udział produkcji przemysłowej, lepiej radziły sobie w trakcie kryzysu. Doskonałym tego przykładem są Stany Zjednoczone, gdzie w 2011 roku gospodarka tego kraju wróciła do stanu sprzed kryzysu, a stało się to głównie dzięki odradzającemu się przemysłowi, który był odpowiedzialny za blisko $40 \%$ nowego wzrostu gospodarczego. Zasadniczymi czynnikami sukcesu amerykańskiej gospodarki były m.in. wzrost produktywności poprawiającej się w tempie 5,0\% rocznie oraz rewolucja łupkowa, dzięki której przedsiębiorcy w USA mają dostęp do taniej energii (Bendyk 2014, s. 64). Dynamiczny sektor produkcyjny ponownie uważany jest za niezbędny element innowacyjnych i szybko rozwijających się gospodarek. Te wszystkie argumenty spowodowały zwrócenie baczniejszej uwagi na zagadnienia polityki przemysłowej i niejako przywróciły to pojęcie do łask, wprowadzając je ponownie do przestrzeni publicznej dyskusji (Ulbrych 2013, s. 48; Stöllinger i in. 2013, s. 1). 
Obecnie prowadzona polityka przemysłowa znacznie różni się od typowej polityki przemysłowej realizowanej choćby po II wojnie światowej. Wtedy polityka ta miała charakter interwencjonizmu państwowego, jej zadaniem była stabilizacja gospodarki i utrzymanie spokoju społecznego. Można powiedzieć, że w gruncie rzeczy jej zadaniem była ochrona własnej gospodarki przed konkurencją międzynarodową. Obecna polityka przemysłowa skupia się natomiast na wspieraniu zdolności konkurencyjnych w warunkach otwartej gospodarki globalnej. Ma ona za zadanie oddziaływanie na poszczególne obszary, z uwzględnieniem konkurencyjności całej gospodarki krajowej, a nie jedynie poszcze-gólnych wspieranych sektorów. Polityka ta nastawiona jest na osiągnięcie strate-gicznych celów długofalowych, w miejsce koncentrowania się na osiąganiu celów doraźnych. Należy w tym miejscu podkreślić, że polityka taka nie może być bezkrytycznie kopiowana $\mathrm{z}$ innych krajów, lecz musi być stworzona od podstaw, z uwzględnieniem cech specyficznych danej gospodarki narodowej (Geodecki i in. 2013, s. 123-124).

\section{Czym jest polityka przemysłowa?}

Zarówno w literaturze ekonomicznej, jak i w praktyce gospodarczej pojęcie „polityka przemysłowa” jest różnie interpretowane, poza tym stosunek do polityki przemysłowej jest krańcowo zróżnicowany - od aprobaty do negacji. Niezależnie od odmienności interpretacyjnych należy podkreślić, że jest to pojęcie podlegające ewolucji, zarówno pod wpływem warunków wewnętrznych (np. poziom rozwoju społeczno-gospodarczego czy uwarunkowania ustrojowo-systemowe), jak i zewnętrznych (np. sytuacja międzynarodowa, poziom zadłużenia wobec zagranicy czy możliwości eksportowe i importowe). Z tradycyjnego punktu widzenia polityka przemysłowa jest definiowana jako zestaw decyzji politycznych i środków, które mają wpływ na strukturę i rozwój sektora produkcji przemysłowej. W ramach polityki gospodarczej tradycyjna polityka przemysłowa jest rozumiana jako część polityki strukturalnej i obejmuje te decyzje oraz środki, które są bezpośrednio i celowo ukierunkowane na zmianę struktury przemysłu (Hochfeld 2010, s. 10). H. Kazarowicz i A. Skowrońska (Kazarowicz, Skowrońska 2005, s. 20) uważają z kolei, że „polityka przemysłowa jest swojego rodzaju klamrą spinającą i koordynującą wiele różnorodnych środków i zagadnień usytuowanych poza samym przemysłem". Jeszcze inaczej definiują politykę przemysłową P. Bianchi i S. Labory (Bianchi, Labory 2011a, s. 3), którzy twierdzą, iż obejmuje ona wszelkie działania przyczyniające się do restrukturyzacji przemysłu i rozwoju nowych branż. Ich zdaniem polityka przemysłowa nie ogranicza się zatem do pomocy państwowej czy polityki badań i rozwoju, lecz stanowi zestaw działań umacnianych przez instrumenty, których celem jest wspieranie poszczególnych dróg rozwoju przemysłu. Z. Bartosik (Bartosik 1993, s. 21, cyt. za: Ślusarczyk 2009, s. 402) twierdzi natomiast, że ,polityka przemysłowa, łącząca w sobie elementy polityki makroekonomicznej z polityką stwarzania warunków sprzyjających rozwojowi konkurencji, była i jest pozytywną reakcją na niedoskonałość rynku. Stanowi więc ona podstawowy instrument, jakim rząd oddziałuje na przemiany strukturalne w przemyśle, nadając im pożądany kierunek i tempo" (1993, s. 21, cyt. za: Ślusarczyk 2009, s. 402). 
Jako główny cel polityki przemysłowej uznać można pobudzanie wzrostu gospodarczego, uzyskiwane dzięki unowocześnianiu, racjonalizacji oraz intensyfikacji procesów wytwórczych. Władze publiczne mają zatem czynnie zaangażować się w sferę nauki i rozwoju tak, by przełożyło się to na szybszy transfer osiągnięć naukowych do sfery życia gospodarczego (Nagórny 2011, s. 476-477).

Polityka przemysłowa może wpływać na gospodarkę pośrednio lub bezpośrednio. Wpływ pośredni mają przede wszystkim warunki ramowe, jak np. sposób funkcjonowania rynków finansowych, prawne aspekty prowadzenia działalności, system administracji państwowej czy jakość edukacji. Za wpływ bezpośredni uznać natomiast należy wspieranie konkretnych gałęzi przemysłu, firm czy technologii (European Competitiveness Report 2013 ... 2013, s. 136).

\section{Polityka przemysłowa w Unii Europejskiej}

Literatura przedmiotu dzieli politykę przemysłową po II wojnie światowej na trzy fazy: pierwsza faza obejmuje lata 1950-1970 minionego stulecia, faza druga to lata 1971-2000, natomiast ostatnia faza rozpoczęła się po roku 2000 i trwa do dziś. W tym czasie polityka przemysłowa ewoluowała od interwencjonizmu państwowego, przez leseferyzm, aż po obecną formę, skupioną na ułatwianiu koordynacji i pomocy w budowie konkurencyjnych gospodarek (Dhéret i in. 2014, s. 12).

Podobnie wyglądała ewolucja polityki przemysłowej Unii Europejskiej. $\mathrm{W}$ pierwszej fazie była ona w zasadzie wewnętrzną sprawą poszczególnych państw członkowskich. Pierwszy okres unijnej polityki przemysłowej charakteryzował się podejściem interwencjonistycznym i selektywnym, co objawiało się poprzez wspieranie wybranych, najczęściej schyłkowych gałęzi przemysłu, uznane przez poszczególne państwa za najważniejsze dla ich gospodarek. Drugi etap obejmował już szereg działań zbiorowych, wspólnych dla wszystkich państw członkowskich. Interwencjonizm państwowy zastąpiono wsparciem horyzontalnym. Trzeci etap unijnej polityki przemysłowej stanowi odpowiedź na znaczący wzrost wydajności przemysłu Stanów Zjednoczonych, osiągnięty dzięki rozwojowi technologii informacyjnych. W roku 2000 przyjęto Strategię Lizbońską, w której wskazano na gospodarkę opartą na wiedzy jako warunek sprostania międzynarodowej konkurencji. W kolejnych latach opracowano jeszcze kilka dokumentów komunikujących zmiany w obranej strategii, wymuszonych głównie przez potrzebę dostosowania gospodarek nowych państw członkowskich do wytycznych Wspólnoty. Duży nacisk położony został na kwestie związane ze zrównoważonym rozwojem, a także na rozwój sieci wspierających współpracę między przedsiębiorstwami, jednostkami badawczymi i uczelniami oraz władzami publicznymi, co przełoży się bezpośrednio na zwiększenie konkurencyjności przemysłu (Bianchi, Labory 2011b, s. 134; Ślusarczyk 2009, s. 402; Kot, Brzeziński 2015, s. 101-112).

Kryzys gospodarczy zapoczątkowany w 2008 roku wymusił ponowne pochylenie się decydentów ze Wspólnoty nad kwestią polityki przemysłowej. Niewielki poziom wzrostu gospodarczego krajów członkowskich oraz powrót państw do interwencjonizmu w celu ratowania narodowych gospodarek stały się przyczyną kolejnych debat $\mathrm{w}$ kwestii polityki przemysłowej. Z pewnością przykład odradza- 
jącego się przemysłu w Stanach Zjednoczonych dał motywację decydentom w Unii Europejskiej do reindustrializacji Wspólnoty, tym bardziej że dla Europy przemysł jest jeszcze ważniejszy niż dla USA, ponieważ odpowiada za $80 \%$ unijnego eksportu i w przemyśle lokowanych jest blisko $80 \%$ prywatnych inwestycji w badania i rozwój (Bendyk 2014, s. 65). Uzmysłowiono sobie, że bez silnego przemysłu nie da się zbudować silnej, konkurencyjnej gospodarki. Z pewnością nie będzie to zadaniem łatwym, gdyż jednocześnie Unia przyjęła surową politykę klimatycznoenergetyczną, a europejscy przemysłowcy ponoszą dwukrotnie wyższy koszt zużycia energii niż przedsiębiorstwa w Stanach Zjednoczonych. W odpowiedzi na te problemy Komisja Europejska opublikowała w ostatnich latach szereg komunikatów przedstawiających zmodyfikowane podejście do problematyki polityki przemysłowej. Do podstawowych jej zadań zaliczono m.in.: zwiększenie produktywności przemysłu wytwórczego i powiązanych $\mathrm{z}$ nim usług, tworzenie silnego i konkurencyjnego łańcucha wartości w przemyśle wytwórczym, tworzenie warunków korzystnych dla rozwoju podmiotów z sektora MŚP oraz dostosowanie przemysłu do zmian w globalnej gospodarce. Działania prowadzone w ramach unijnej polityki powinny być ukierunkowane na wprowadzanie takich zmian, jak choćby: poprawa jakości otoczenia biznesu, usprawnienie działania administracji publicznej, zwiększenie zdolności innowacyjnych przedsiębiorstw oraz poprawa efektywności energetycznej (Zintegrowana polityka przemysłowa... 2010, s. 36).

Duże znaczenie dla polityki przemysłowej Unii Europejskiej ma również komunikat z dnia 10 października 2012 r., stanowiący niejako strategię reindustrializacji Wspólnoty. Założono w nim zwiększenie udziału produkcji przemysłowej w strukturze PKB Unii do $20 \%$ w 2020 roku. Wskazane zostały również cztery filary, na których powinna opierać się nowa, wzmocniona polityka gospodarcza. Filarami tymi są: inwestycje $\mathrm{w}$ innowacje, poprawa warunków rynkowych, zwiększenie dostępu do kapitału, a także poprawa jakości kapitału ludzkiego. Pierwszy filar szczególnie istotny jest w przypadku sektorów zaawansowanych technologii, charakteryzujących się dużym potencjałem wzrostu i wysokim poziomem zatrudnienia. Drugi filar obejmuje działania dotyczące wpierania przedsiębiorczości w sferze jednolitego rynku cyfrowego, ochrony własności intelektualnej oraz rozwoju i internacjonalizacji podmiotów z sektora MŚP. Filar trzeci dotyczy bardziej optymalnego ukierunkowania przepływu środków publicznych oraz zniesienia barier przepływu środków prywatnych i przepływów transgranicznych. Realizacja ostatniego filaru nastąpić powinna poprzez lepsze dostosowanie oferty edukacyjnej do wymagań współczesnej gospodarki (Ulbrych 2013, s. 59; Silniejszy przemyst europejski... 2012, s. 4). W komunikacie tym przedstawiono również priorytetowe obszary działania, którymi są: zaawansowane technologie produkcyjne, kluczowe technologie wspomagające, bioprodukty, zrównoważona polityka w zakresie przemysłu i budownictwa oraz surowców, ekologicznie czyste pojazdy oraz inteligentne sieci i infrastruktura cyfrowa (Silniejszy przemyst europejski... 2012, s. 4).

W najnowszym dokumencie unijnym dotyczącym polityki przemysłowej z dnia 22 stycznia 2014 r. zwrócono uwagę na powiązania przemysłu z pozostałymi gałęziami gospodarki. Zależności te nie ograniczają się tylko do przetwórstwa przemysłowego, lecz obejmują całe łańcuchy dostaw - począwszy od dostaw surowców i energii, na usługach dla przedsiębiorstw (m.in. logistyka) i konsumentów (obsługa 
posprzedażowa) kończąc. Integracja ta powoduje, że znaczenie przemysłu w gospodarce jest znacznie większe, niż wskazywałaby zwykła analiza udziału przetwórstwa przemysłowego w strukturze PKB. Jak podkreślono w komunikacie, przemysł odpowiada za około 80\% eksportu całej Unii Europejskiej, ponadto właśnie w przemyśle lokowanych jest ponad $80 \%$ nakładów na innowacje i badania naukowe. Ponadto każde nowe miejsce pracy w przemyśle generuje powstanie 0,5-2 miejsc pracy w innych sektorach (Działania na rzecz odrodzenia... 2014, s. 1).

\section{Polityka przemyslowa w Polsce}

Polskiej polityce przemysłowej od początku lat dziewięćdziesiątych poświęcono wiele uwagi i przygotowano wiele dokumentów regulujących jej zakres, cele i zadania (por. Ślusarczyk 2010, s. 5-35). W okresie transformacji systemowej polska polityka przemysłowa przeszła cztery zasadnicze etapy (Płowiec (red.) 2010, s. 170; Pełka 1998, s. 12; Muńko 1996, s. 15):

1. W pierwszym z nich (1989-1991) polityka gospodarcza skoncentrowana była na realizacji programu stabilizacyjnego oraz na walce $\mathrm{z}$ inflacją, co spowodowało przesunięcie problemów restrukturyzacyjnych gospodarki na dalszy plan. Na tym etapie znacznie ograniczone zostały dotacje państwa dla przemysłu. Ówczesna ,polityka przemysłowa" realizowana była w sposób chaotyczny, bez programów koniecznych zmian w strukturze potencjału produkcyjnego i produkcji.

2. W etapie drugim (połowa 1991-1994) podjęto próby ustalenia zasad polityki przemysłowej. Ministerstwo Przemysłu i Handlu przystąpiło do prac nad założeniami polityki przemysłowej, które zawierały projekty programów restrukturyzacji wybranych branż przemysłu (tzw. studia sektorowe). W 1991 roku zawarty został Układ Europejski ograniczający swobodę prowadzenia polityki przemysłowej przez narzucenie reguł udzielania pomocy państwa.

3. W trzecim etapie, zapoczątkowanym pod koniec roku 1994, przyjęto dokument Program polityki przemystowej na lata 1995-1997. Międzynarodowa konkurencyjność polskiego przemystu. Akceptacja tego programu oznaczała równocześnie przejście od polityki przemysłowej (defensywnej), koncentrującej swe działania na ochronie i restrukturyzacji niektórych gałęzi tradycyjnych, do polityki promocji gałęzi przyszłościowych i eksportowych (aktywnej).

4. Od roku 1996 polityka przemysłowa Polski znalazła się na czwartym etapie w procesie dostosowywania gospodarki kraju do wymogów wolnego rynku. W nowej „erze” polityki przemysłowej zakładano coraz ściślejsze dostosowywanie się do reguł konkurencji w Unii Europejskiej, jak również wypełnianie postanowień Układu Europejskiego w tym zakresie.

W toczącej się w Polsce w pierwszych latach transformacji polemice o polityce przemysłowej przeważały negatywne doświadczenia związane z kształtowaniem struktury produkcji przez państwo w systemie gospodarki centralnie planowanej. Gospodarka nakazowa wykluczała funkcjonowanie mechanizmu rynkowego, a państwo podejmowało nawet najdrobniejsze decyzje dotyczące rozwoju przemysłu. W rezultacie wszystkie błędy z tym związane przypisano interwencjonizmowi pań- 
stwowemu, a naczelną wytyczną warunkującą politykę przemysłową stało się twierdzenie ministra T. Syryjczyka: ,najlepsza polityka przemysłowa to brak tej polityki”.

Zwolennicy polityki przemysłowej stanowili jednak najliczniejszą grupę polskich ekonomistów. Popierali oni ideę oddziaływania państwa na rozwój przemysłu nie tylko przy pomocy narzędzi polityki makroekonomicznej (czyli stopy procentowej, kursu walutowego czy ulg podatkowych), ale również poprzez zastosowanie wielu innych narzędzi polityki gospodarczej (Bożyk 2000, s. 142-145).

Formułowaniu polskiej polityki przemysłowej towarzyszyły znaczące ograniczenia, którymi były: brak społecznego consensusu dla realizowanej polityki gospodarczej, a przede wszystkim brak środków finansowych na jej prowadzenie. Niejednokrotnie można przeczytać opinię, że za fiasko polityki przemysłowej odpowiadają: relacje polityczne, lobbujące konkretne przemysły, a także związki zawodowe wielkich zakładów, blokujące procesy prywatyzacji. W rezultacie, pomimo przygotowanych dokumentów i formułowanych celów i zadan polityki przemysłowej, ta realizowana była wybiórczo, chaotycznie i często w sprzeczności $\mathrm{z}$ założeniami innych polityk.

\section{Polski przemysł na tle gospodarek innych krajów Unii Europejskiej}

Sformułowanie planu skutecznej polityki przemysłowej dla Polski nie jest zadaniem łatwym. $Z$ jednej strony należałoby skupić się na branżach, które rokują największe nadzieje rozwoju i decydują o konkurencyjności gospodarczej kraju, $\mathrm{z}$ drugiej natomiast kształtowanie polskiej polityki przemysłowej jest $\mathrm{w}$ pewien sposób ograniczone przez unijne wytyczne. Narodowa polityka przemysłowa kraju członkowskiego UE musi się bowiem wpisywać w ogólne założenia polityki przemysłowej całej Wspólnoty (przedstawione powyżej). W przypadku Polski sprawa jest o tyle trudna, że sektory strategiczne naszej gospodarki nie do końca odpowiadają priorytetom unijnej polityki.

Autorzy raportu Polityka przemystowa gwarantem zatrudnienia przedstawiają trzy główne czynniki konkurencyjności polskiego przemysłu, którymi są: relatywnie niskie koszty pracy, wysoka chłonność rynku wewnętrznego oraz elastyczność kursu złotego (Kiewra i in. 2011, s. 42). Nie są to jednak atuty, jakimi w dłuższej perspektywie konkurować może państwo, które chce się gospodarczo rozwijać, a docelowo awansować do grupy krajów wysoko rozwiniętych. Należy zatem na bazie posiadanych atutów stworzyć program dostosowania polskiego przemysłu do zmieniających się warunków (i wymagań Unii Europejskiej) tak, by w przyszłości móc czerpać z tego największe korzyści.

Głębsza analiza stanu polskiego przemysłu i możliwych dróg rozwoju wymaga przeglądu ogólnej sytuacji makroekonomicznej Polski. Według danych Głównego Urzędu Statystycznego w 2014 roku PKB Polski wyniósł 1728677 mln zł, co w przeliczeniu na jednego mieszkańca dało 45495 zł. Wartość PKB w stosunku do poprzedniego roku wzrosła o 4,0\% (w 2013 roku o 1,7\% w stosunku do roku 2012). Wartość eksportu w 2014 roku wyniosła 693 471,6 mln zł i była o 7\% wyższa niż w roku wcześniejszym. Z kolei stopa bezrobocia osiągnęła w Polsce w roku 2014 poziom średnio 12,0\% - wskaźnik ten obniżył się w porównaniu z 2013 rokiem o 1,4 punktu procentowego. Wartość nakładów inwestycyjnych w polskiej 
gospodarce w 2014 roku równała się 248895 mln zł i była wyższa niż w roku 2013 o ok. 7,7\%. Warto przy tym dodać, że nakłady inwestycyjne w przemyśle wzrosły w 2014 roku w stosunku do roku poprzedniego o 18,3\% (w przetwórstwie przemysłowym miernik ten wyniósł 17,8\%). Tę znaczącą poprawę wyróżnionych mierników potwierdza fakt, że w 2013 roku nakłady inwestycyjne w przemyśle wzrosły w stosunku do roku 2012 o 4\%, a w przetwórstwie przemysłowym o 7\%. Również produkcja sprzedana przemysłu wzrosła w analizowanym okresie o 3,3\% (w 2013 roku o 1,8\% w stosunku do 2012 roku), przy czym największy wzrost (o 4,6\%) odnotowano w przetwórstwie przemysłowym.

Siłę i konkurencyjność polskiej gospodarki, ze szczególnym uwzględnieniem przemysłu, można obiektywnie zobrazować, dokonując jej porównania z innymi krajami. W niniejszym opracowaniu analiza skupi się głównie na porównaniu Polski z wybranymi krajami Wspólnoty, ze szczególnym uwzględnieniem takich krajów jak: Czechy, Słowacja i Węgry, czyli państwa Grupy Wyszehradzkiej, charakteryzujące się podobnymi uwarunkowaniami ekonomicznymi i geopolitycznymi, Hiszpania i Włochy, czyli państwa o podobnej strukturze gospodarczej, a także Niemcy, Francja i Wielka Brytania, czyli największe państwa Unii, będące jednymi z liderów gospodarczych i de facto mające główny wpływ na wiele decyzji podejmowanych w Unii Europejskiej.

Pierwszym i chyba najważniejszym wskaźnikiem pozwalającym określić sytuację gospodarczą na tle innych krajów jest wskaźnik dynamiki PKB. Jego wartość w latach 2006-2014 zaprezentowana została na Rysunku 1.

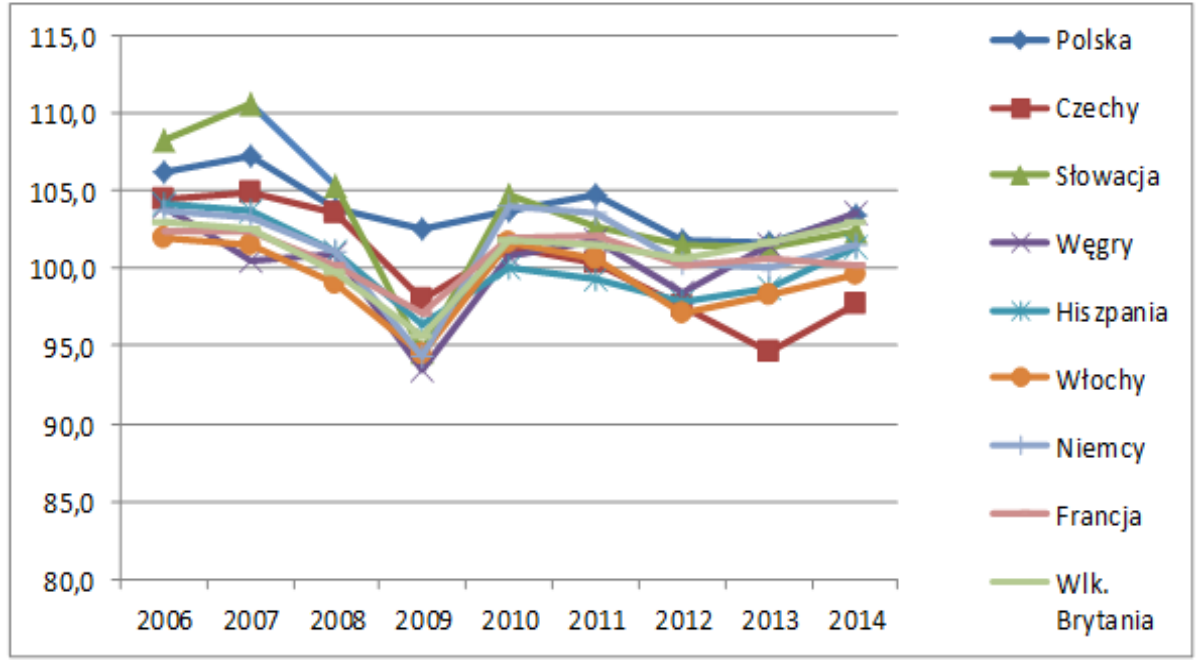

Rysunek 1. Dynamika PKB w wybranych krajach w latach 2006-2014 [\%]

Źródło: Opracowanie własne na podstawie danych Eurostat

Dane na wykresie wyraźnie pokazują, że największy kryzys w krajach Unii Europejskiej przypadł na 2009 rok. Wartość produktu krajowego brutto większości państw członkowskich była niższa niż w roku wcześniejszym. Wyjątkiem jest tu 
Polska, czyli jedyny spośród analizowanych krajów, w którym wskaźnik dynamiki PKB osiągnął wartość powyżej $100 \%$. Najgorsza sytuacja miała w tym czasie miejsce na Węgrzech, gdyż wskaźnik dynamiki PKB tego kraju był niższy niż $95 \%$, co oznacza dość sporą recesję. W roku 2010 wszystkie kraje, poza Hiszpanią, wróciły na drogę rozwoju, jednak sytuacja ta nie trwała długo - już w roku 2012 w wielu państwach ponownie dała o sobie znać recesja, która utrzymała się również w 2013 roku. Podobnie jak w roku 2009, problem ten nie dotyczył Polski. $\mathrm{Z}$ analizy tych danych widać zatem wyraźnie, że Polska, jako jeden $\mathrm{z}$ niewielu krajów, potrafiła utrzymać (co prawda niewielki) wzrost gospodarczy. W 2014 roku prawie we wszystkich krajach (poza Francją) zauważa się dalszy wzrost PKB.

Kolejnymi, szczególnie interesującymi z punktu widzenia tematu niniejszego artykułu, wskaźnikami monitorującym sytuację gospodarczą krajów są: udział przemysłu w wartości produktu krajowego oraz udział zatrudnionych w przemyśle osób w ogólnej liczbie pracujących. Dane związane z tymi obszarami badawczymi zaprezentowane zostały na Rysunku 2 i Rysunku 3.

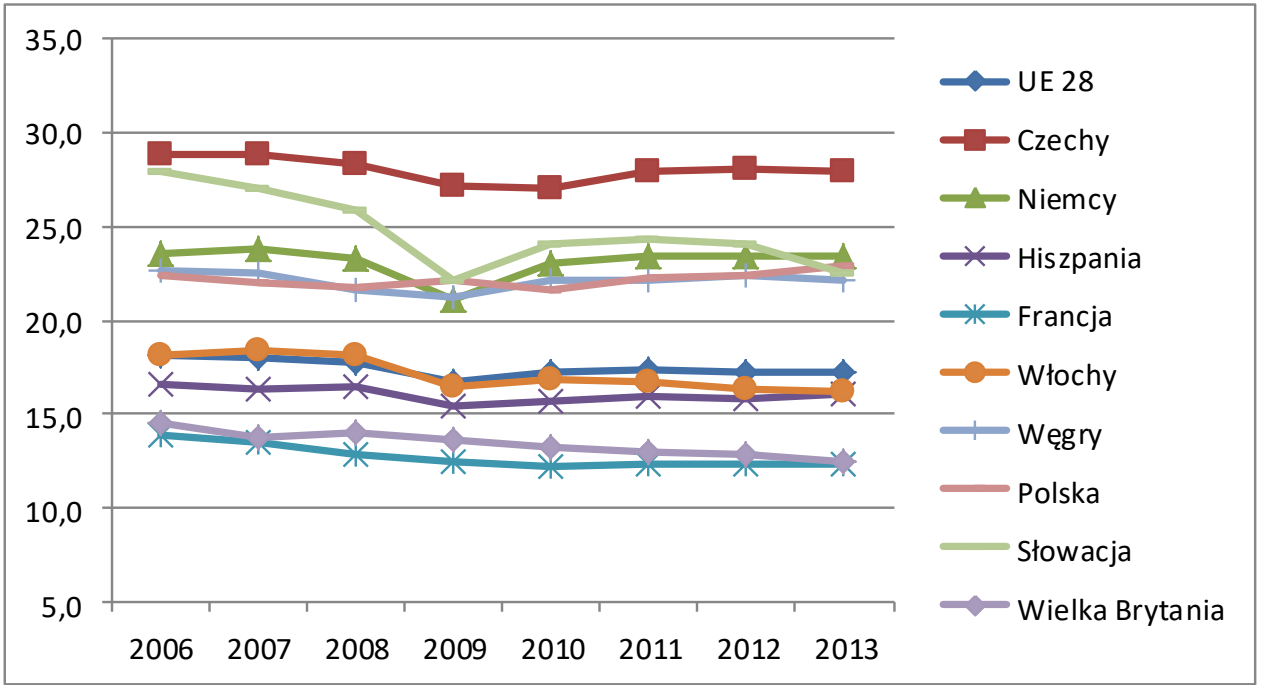

Rysunek 2. Udzial przemysłu w PKB gospodarek wybranych krajów w latach 2006-2013 [\%]

Brak danych dotyczących 2014 roku.

Źródło: Opracowanie własne na podstawie danych Eurostat

Zarówno w Unii Europejskiej jako całości, jak i w poszczególnych państwach członkowskich, udział przemysłu w PKB przez cały analizowany okres kształtował się na dość stabilnym poziomie. Wskaźnik ten zdecydowanie najwyższy szczebel osiąga w Czechach, gdzie wynosi ponad 25\%, najniższy z kolei jest we Francji w żadnym roku nie osiągnął on wartości 15\%. We wszystkich krajach w roku 2009 nastąpił spadek udziału przemysłu w PKB, przy czym w większości przypadków od roku 2010 następuje powolny wzrost wartości tego wskaźnika. Na tym tle sytu- 
acja polskiego przemysłu kształtuje się w miarę stabilnie. Udział przemysłu w PKB Polski oscyluje $\mathrm{w}$ granicach $22 \%$ i jest wyższy niż średnia unijna wynosząca ok. 17\%. Pamiętając o tym, że jednym z celów UE na 2020 rok jest osiągniecie 20-procentowego udziału przemysłu w PKB, można uznać, że Polska pozytywnie wpisuje się w tę strategię. Obecny poziom tego wskaźnika stanowi dla naszego kraju dobry punkt wyjścia i daje nadzieję na utrzymanie, a nawet przyspieszenie tempa rozwoju gospodarczego (przy podjęciu odpowiednich działań wspierających).

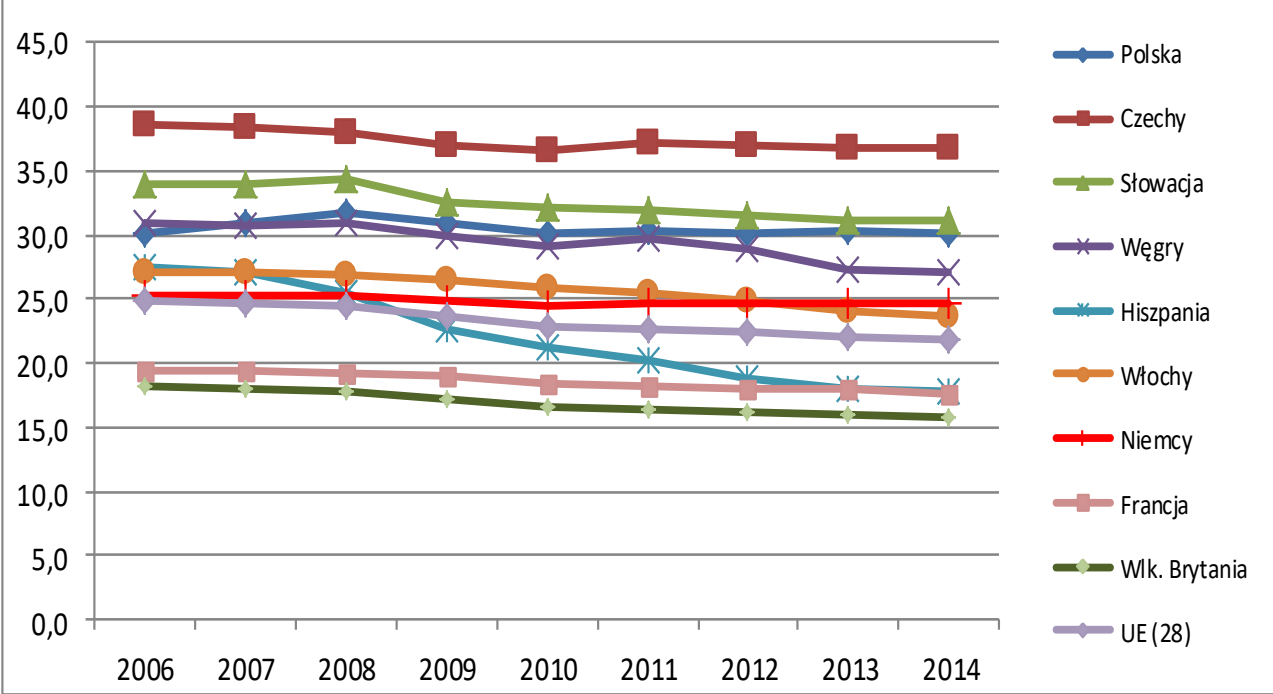

Rysunek 3. Udział osób zatrudnionych w przemyśle w ogólnej liczbie pracujących w wybranych krajach w latach 2006-2014 [\%]

Źródło: Opracowanie własne na podstawie danych Eurostat

Unijna średnia udziału zatrudnionych w przemyśle osób w ogólnej liczbie pracujących w latach 2006-2014 kształtowała się w granicach od 24,8\% do $21,9 \%$, przy czym był to konsekwentny spadek. Spośród wymienionych na wykresie państw, największy ubytek pracujących w przemyśle, bo aż o 9,6 punktu procentowego, odnotowała Hiszpania, która wraz z Wielką Brytanią oraz Francją znajduje się poniżej średniej unijnej. W pozostałych krajach udział zatrudnionych w przemyśle osób w ogólnej liczbie pracujących odnotowano powyżej unijnej średniej, przy czym niekwestionowanym liderem w tym obszarze są Czechy, ze wskaźnikiem na poziomie 36,7\% w 2014 roku. Polska i Niemcy to kraje, które mogą pochwalić się $\mathrm{w}$ zasadzie stabilnym udziałem pracujących $\mathrm{w}$ przemyśle w badanym okresie (Polska nieco ponad 30\%, Niemcy średnio 24,5\%). Pozostałe kraje: Słowacja, Węgry i Włochy w badanym okresie odnotowały spadki omawianego wskaźnika o ok. 3\%-4\%. 
Z pewnością interesującym dla wzbogacenia podjętych rozważań będzie także spojrzenie na dane dotyczące udziału produkcji hi-tech w eksporcie w wybranych krajach unijnych.

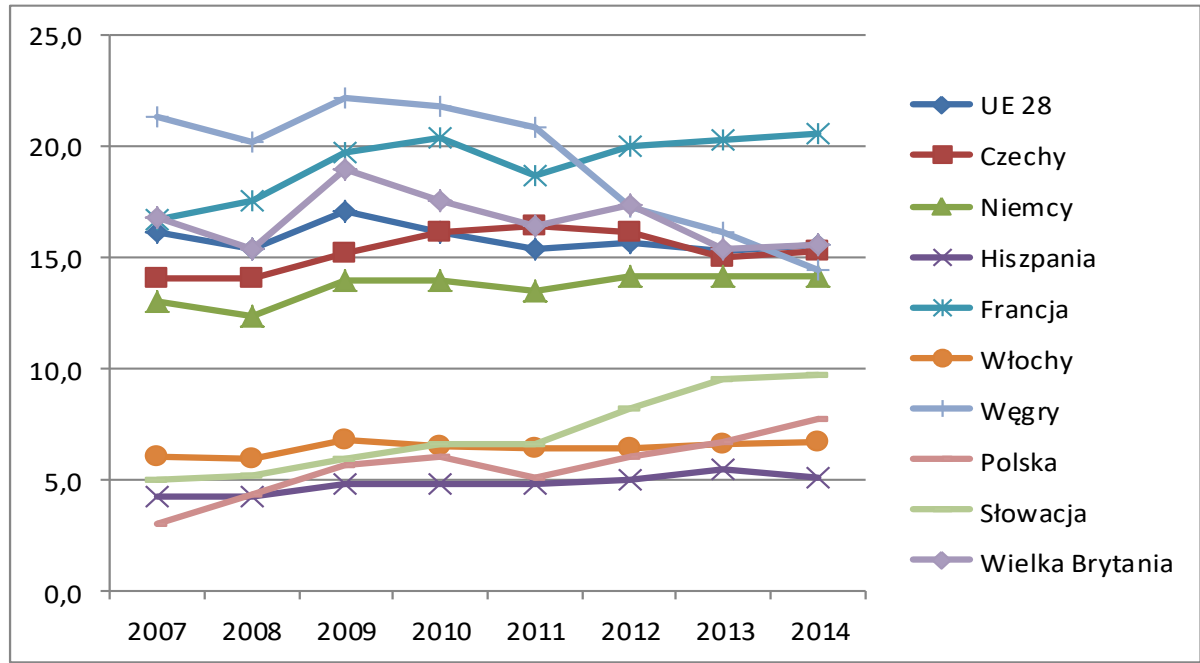

Rysunek 4. Udzial produkcji hi-tech w eksporcie w wybranych krajach w latach 2007-2014 [\%]

Źródło: Opracowanie własne na podstawie danych Eurostat

Pośród analizowanych krajów występuje znaczna rozbieżność w kwestii udziału produkcji wysokiej technologii w eksporcie. Do roku 2011 najwyższy był on w przypadku Węgier, jednak od roku 2012, w związku ze znacznym spadkiem wielkości produkcji hi-tech w tym kraju, na pozycję lidera wysunęła się Francja. Średnio, w całym analizowanym okresie, najniższą wartość wskaźnik ten przyjmuje w Hiszpanii, gdzie oscyluje w granicach 5\%. W pierwszej kolejności, na wykresie zauważyć można, że analizowane kraje dzielą się zasadniczo na dwie grupy: państwa, w których udział produkcji hi-tech w eksporcie kształtuje się na poziomie ok. 5\%, oraz te, w których udział ten wynosi ok. 15\%-20\%. W pierwszej grupie, w której znajduje się niestety również Polska, na uwagę zasługuje Słowacja, która od 2011 roku znacznie zwiększa udział produktów wysokiej technologii w eksporcie i w roku 2014 zbliżyła się do granicy 10\%. Na tym tle Polska wypada niekorzystnie - co prawda z wyjątkiem roku 2011 udział produkcji hi-tech w eksporcie rośnie, jednak nadal jest to jedna $\mathrm{z}$ najniższych wartości wśród analizowanych krajów. Wartość ta jest zdecydowanie niższa niż średnia dla Unii Europejskiej wynosząca ok. 15\%. Należy zatem podjąć w tym obszarze intensywne działania, gdyż to właśnie przemysł wysokiej technologii pozwala na kształtowanie przewagi konkurencyjnej i jest jednym z priorytetów wspólnej polityki przemysłowej Unii Europejskiej. Przewagi konkurencyjnej w sektorze hi-tech nie da się jednak osiągnąc bez znacznych nakładów na badania i rozwój. Wielkość nakładów na badania i rozwój jako procent PKB przedstawiona została na Rysunku 5. 


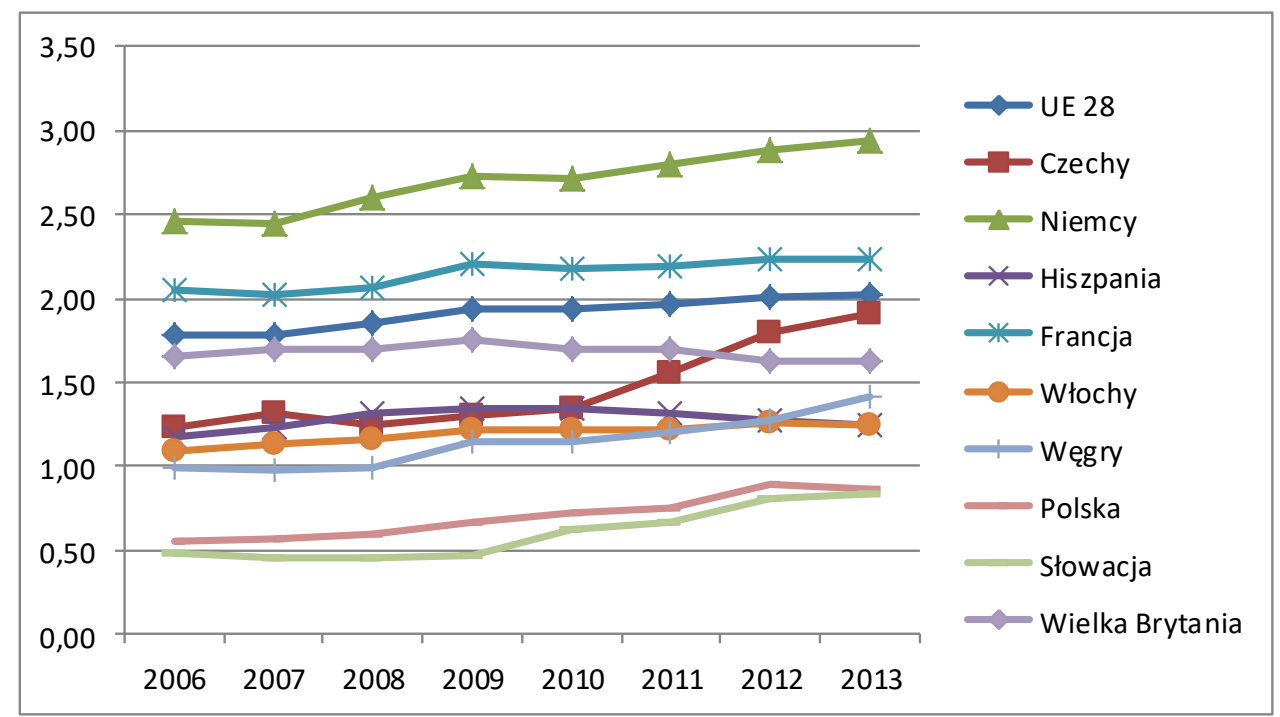

Rysunek 5. Nakłady na badania i rozwój jako procent PKB wybranych krajów w latach 2006-2013 [\%]

Brak danych dotyczących 2014 roku.

Źródło: Opracowanie własne na podstawie danych Eurostat

Zdecydowanie najwyższą część PKB na badania i rozwój poświęcają Niemcy. Nakłady te cały czas rosną i kształtują się na poziomie od prawie $2,5 \% \mathrm{w}$ roku 2006 do niecałych 3\% w 2013 roku. Na drugim biegunie znajduje się Słowacja, w której na ten cel przeznaczono w 2013 roku nieco ponad 0,8\% wartości PKB. Nieznacznie lepiej niż na Słowacji, sytuacja ma się w Polsce. Właśnie te dwa kraje najbardziej odstają od reszty analizowanych państw. Są również bardzo daleko od osiągnięcia średniej unijnej, która w 2013 roku wyniosła ponad 2\%. Warto zwrócić jeszcze uwagę na dwa kraje: Hiszpanię i Czechy. Hiszpania jest jedynym państwem, w którym - po początkowym wzroście - w ostatnim okresie wartość analizowanego wskaźnika spada. Natomiast Czechy odnotowały największy wzrost tego wskaźnika, w roku 2013 osiągając już prawie średnią unijną. Nasi południowi sąsiedzi udowadniają zatem, że w ciągu kilku lat można w tym zakresie nadrobić wieloletnie opóźnienia. Chcąc skutecznie konkurować na międzynarodowym rynku, Polska powinna zatem iść za ich przykładem i znacząco zwiększyć nakłady na badania i rozwój tak, by za kilka lat osiągnąć przynajmniej poziom unijnej średniej.

O przewadze konkurencyjnej przemysłu danego kraju nie decyduje jednak tylko wielkość nakładów na badania i rozwój. Środki te muszą bowiem zostać efektywnie wykorzystane, a to $\mathrm{z}$ racji wielu różnych czynników nie zawsze jest realizowane. Badania i rozwój mają jednak bardzo duże znaczenie dla poziomu innowacyjności gospodarki. Innowacyjność jest $\mathrm{z}$ kolei cechą bardzo pożądaną, zarówno z perspektywy gospodarek krajowych, jak i gospodarki całej Wspólnoty Europejskiej. Dlatego też Unia Europejska cyklicznie publikuje raporty oceniające państwa 
członkowskie właśnie w aspekcie innowacyjności (por. Szajt 2012, s. 28-38). O poziomie innowacyjności danej gospodarki decydują w tych raportach czynniki pogrupowane w następujące kategorie: zasoby ludzkie, systemy badawcze, finansowanie i wsparcie, inwestycje przedsiębiorstw, przedsiębiorczość, wartości intelektualne, innowatorzy, efekty ekonomiczne. Na podstawie tych czynników wyliczany jest Sumaryczny Indeks Innowacyjności. Jego wartość kształtuje się w granicach od 0 (brak innowacyjności) do 1 (pełna innowacyjność). Wartości Sumarycznego Indeksu Innowacyjności za rok 2013 dla wszystkich krajów UE przedstawione zostały na Rysunku 6. Ze względu na wartość tego indeksu kraje dzielone są na 4 grupy: liderzy innowacji (kolor zielony), „goniący” (kolor niebieski), umiarkowani innowatorzy (kolor żółty) oraz skromni innowatorzy (kolor czerwony). Dodatkowo na wykresie przy każdym państwie, w nawiasie podano wskaźnik wzrostu indeksu od poprzedniej edycji raportu.

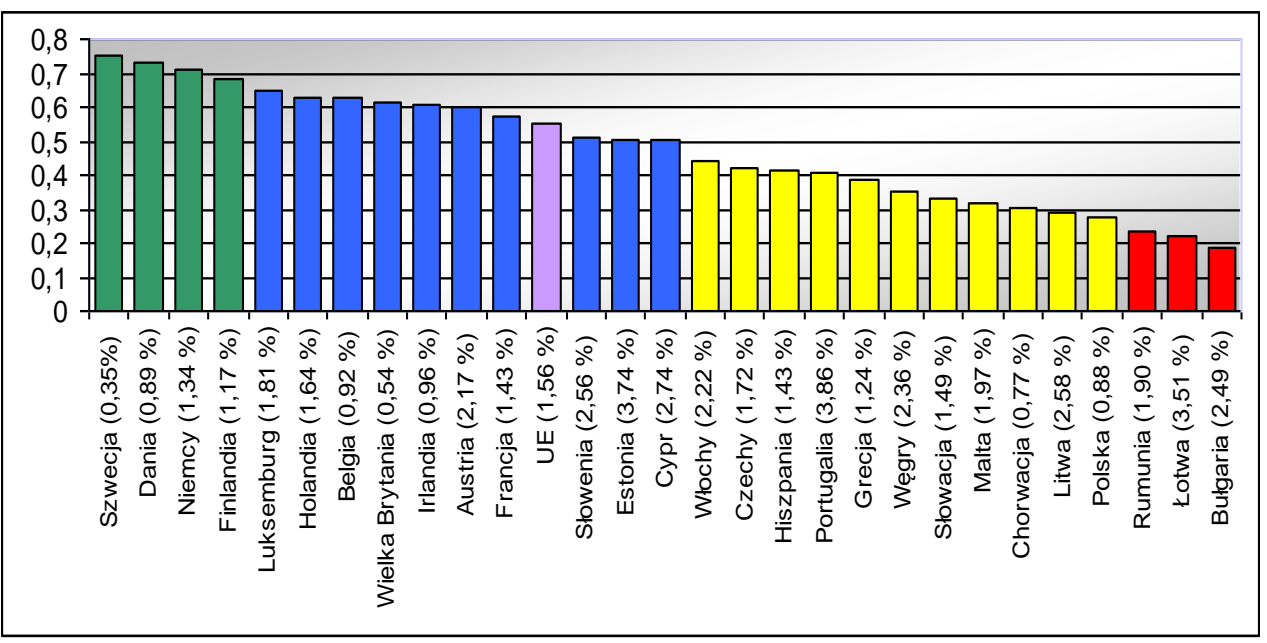

\section{Rysunek 6. Sumaryczny Indeks Innowacyjności krajów Unii Europejskiej}

Źródło: Opracowanie własne na podstawie (Hollanders, Es-Sadki 2014, s. 92)

Zdecydowanie najmniej liczne są dwie grupy skrajne, czyli liderzy innowacji oraz skromni innowatorzy. Średni poziom indeksu dla całej Unii Europejskiej sytuuje ją w gronie ,goniących”. Polska znajduje się w grupie umiarkowanych innowatorów, jednak zajmuje $\mathrm{w}$ tym gronie ostatnie miejsce - w rankingu innowacyjności krajów UE plasuje się zatem dopiero na 25. miejscu. Tak naprawdę nasz kraj posiada wartość Sumarycznego Indeksu Innowacyjności jedynie niewiele wyższą od krajów znajdujących się w najsłabszej grupie. Nie jest to z pewnością sytuacja korzystna, oznaczając, że Polska jest państwem mało innowacyjnym, co z kolei znacznie utrudnia konkurencję na rynku międzynarodowym. Ponadto nasz kraj osiągnął jeden z najniższych wskaźników wzrostu indeksu, co stanowi realne zagrożenie, że kraje znajdujące się w tym rankingu za Polską wkrótce mogą ją wyprzedzić, a pozycja innowacyjnego outsidera raczej nikogo w Polsce nie zadowala. 


\section{Podsumowanie}

Kryzys gospodarczy wywołany spekulacjami na rynkach finansowych wymusił ponowne zwrócenie się w stronę przemysłu, który przez wiele lat skutecznie spychany był na margines gospodarki. By jednak ten powrót do przemysłu zaowocował ożywieniem gospodarczym i wyjściem z recesji, w którą wpadło wiele państw, nie może on być chaotyczny, musi opierać się na konkretnych założeniach i celach długofalowych. Odpowiedzią na te potrzeby jest polityka przemysłowa. Dobrze sformułowana i skutecznie wdrażana, pozwoli na odrodzenie gospodarek dzięki przywróceniu przemysłowi jego znaczenia. Polityka ta musi być jednak dostosowana do obecnych realiów i światowej sytuacji gospodarczej, dlatego też szczególne miejsce zajmuje w niej przemysł wysokich technologii i szeroko pojęta innowacyjność. Właśnie na te obszary ukierunkowana jest nowa polityka Unii Europejskiej z jej priorytetami: zaawansowanymi technologiami produkcyjnymi, kluczowymi technologiami wspomagającymi, bioproduktami, zrównoważoną polityką w zakresie przemysłu i budownictwa oraz surowców, ekologicznie czystymi pojazdami oraz inteligentnymi sieciami i infrastrukturą cyfrową. Jako że unijne założenia w dużej mierze warunkują kierunki krajowych polityk państw członkowskich, Polska również musi dostosować swoją politykę przemysłową do tych założeń. Należy się zatem skupić na rozwoju przemysłu wysokiej technologii, dzięki któremu będzie można skutecznie konkurować na arenie międzynarodowej i zwię-kszyć tempo wzrostu gospodarczego.

Mocną stroną polskiej gospodarki w warunkach światowego kryzysu gospodarczego jest to, że jak do tej pory nie wpadła ona $\mathrm{w}$ recesję. Jednym z powodów takiego stanu rzeczy może być w miarę optymalny udział przemysłu w PKB wynoszący ok. 23\%. Wartość ta jest zbliżona do wyniku, jaki ma osiągnąć UE w 2020 roku. Dużo gorzej wygląda jednak w Polsce kwestia nowoczesności i innowacyjności przemysłu. Udział produkcji hi-tech w eksporcie kształtuje się na poziomie ok. 7\%, czyli zdecydowanie poniżej średniej unijnej. Również nakłady na badania i rozwój są w naszym kraju zdecydowanie za niskie i wynoszą mniej niż 1\% wartości PKB, podczas gdy średnia unijna to $2 \%$ wartości PKB. To wszystko powoduje, że Polska znajduje się dopiero na 25. miejscu w rankingu innowacyjności państw Unii Europejskiej i nazywana jest krajem innowacyjnej stagnacji. Jeśli Polska ma posiadać konkurencyjną gospodarkę, należy sformułować założenia polityki przemysłowej w taki sposób, by wspierały one rozwój nowoczesnych gałęzi przemysłu i ułatwiały wdrażanie rozwiązań innowacyjnych. Nadrzędnym zadaniem jest, aby doprowadzić do spójności polityki klimatycznej, energetycznej i przemysłowej, co będzie miało fundamentalne znaczenie dla rozwoju polskiego przemysłu.

\section{Literatura}

1. Bartosik Z. (1993), Ekonomika i polityka przemysłowa, Wydawnictwo Akademii Ekonomicznej we Wrocławiu, Wrocław.

2. Bendyk E. (2014), Fabryki przyszłości, „Polityka”, nr 47(2985), s. 64-66.

3. Bianchi P., Labory S. (2011a), Industrial Policy after the Crisis. Seizing the Future, Edward Elgar Publishing, Cheltenham. 
4. Bianchi P., Labory S. (2011b), Industrial Policy after the Crisis: the Case of the Emilia-Romagna Region in Italy, "Policy Studies", Vol. 32, Issue 4.

5. Bożyk P. (2000), Polityka gospodarcza Polski 1985-2000, Wydawnictwo FBC - Prywatne Policealne Studium Handlowe, Warszawa.

6. Dhéret C., Morosi M., Frontini A., Hedberg A., Pardo R. (2014), Towards a New Industrial Policy for Europe, EPC ISSUE PAPER, No. 78, http://www.epc.eu/documents/uploads/ pub_4995_towards_a_new_industrial_policy_for_europe.pdf(dostęp: 18.11.2015).

7. Działania na rzecz odrodzenia przemysłu europejskiego (2014), Komunikat Komisji do Parlamentu Europejskiego, Rady, Europejskiego Komitetu Ekonomiczno-Społecznego i Komitetu Regionów, Bruksela.

8. European Competitiveness Report 2013 Towards Knowledge-driven Reindustrialization (2013), Publications Office of the European Union, Luksemburg.

9. Geodecki T., Hausner J., Majchrowska A., Marczewski K., Piątkowski M., Tchorek G., Tomkiewicz J., Weresa M. (2013), Konkurencyjna Polska. Jak awansować w światowej lidze gospodarczej?, Olison's Project, Kraków.

10. Grzeszak A. (2015), Mit hut, „Polityka”, nr 16(3005), s. 40-43.

11. Hochfeld Ch., Kabel C., Acker H., Barth R., Gensch C.O., Kallenbach B., Schmidt G., Timpe Ch. (2010), Sustainable Industrial Policy for Europe: Governing the Green Industrial Revolution, Green European Fundation, Bruksela.

12. Hollanders H., Es-Sadki N. (2014), Innovation Union Scoreboard 2014, Komisja Europejska, Bruksela.

13. Karpiński A. (2015), Pomysł na przemysł, „Polityka”, nr 30(3019), s. 44-45.

14. Kazarowicz H., Skowrońska A. (2005), Polityka przemysłowa, Wydawnictwo Akademii Ekonomicznej we Wrocławiu, Wrocław.

15. Kiewra D., Darteyre P., Jakubowski A., Januszkiewicz T., Portet S., Towalski R., Ulianiuk A., Morvannou P. (2011), Polityka przemysłowa gwarantem zatrudnienia, Wydawnictwo S. Partner, Warszawa.

16. Kot S., Brzeziński S. (2015), Market Orientation Factors in Sustainable Development and Corporate Social Responsibility, “Asian Journal of Applied Sciences”, Vol. 8(2), s. 101-112.

17. Muńko A. (1996), Polska polityka przemysłowa w procesie transformacji i integracji z Unią Europejską, „Wspólnoty Europejskie”, nr 7-8, s. 15-21.

18. Nagórny W. (2011), Rola polityki przemysłowej w strategii rozwoju społeczno-gospodarczego Polski i Unii Europejskiej. Problemy regionalizmu i globalizacji, Prace Naukowe Uniwersytetu Ekonomicznego we Wrocławiu, nr 221, s. 470-479, Wydawnictwo Uniwersytetu Ekonomicznego we Wrocławiu, Wrocław.

19. Pełka B. (1998), Przemysł polski w perspektywie strategicznej, Instytut Organizacji i Zarządzania w Przemyśle ORGMASZ, Warszawa.

20. Płowiec U. (red.) (2000), Polska i Unia Europejska. Stan obecny i wyzwania na przyszłość, Agencja Wydawnicza Placet, Warszawa.

21. Silniejszy przemysł europejski na rzecz wzrostu i ożywienia gospodarczego (2012), Komunikat Komisji do Parlamentu Europejskiego, Rady, Europejskiego Komitetu EkonomicznoSpołecznego i Komitetu Regionów, Bruksela.

22. Stöllinger R., Foster-Mcgregor N., Holzner M., Landesmann M., Pöschl J., Stehrer R. (2013), A 'Manufacturing Imperative' in the EU - Europe's Position in Global Manufacturing and the Role of Industrial Policy, Wiener Institut für Internationale Wirtschaftsvergleiche, Wiedeń.

23. Szajt M. (2012), Zmiana pozycji innowacyjnej regionów w rozszerzającej się Unii Europejskiej, Prace Naukowe Uniwersytetu Ekonomicznego we Wrocławiu, nr 244, s. 28-38, Wydawnictwo Uniwersytetu Ekonomicznego we Wrocławiu, Wrocław. 
24. Ślusarczyk B. (2009), Horyzontalna polityka przemysłowa w Polsce w kontekście uregulowań unijnych, Zeszyty Naukowe Uniwersytetu Szczecińskiego, nr 578, Finanse, Rynki Finansowe, Ubezpieczenia, $\mathrm{nr}$ 24: Determinanty wzrostu wartości przedsiębiorstwa, s. 401-409, Wydawnictwo Naukowe Uniwersytetu Szczecińskiego, Szczecin.

25. Ślusarczyk B. (2010), Industrial Policy Development Towards Sustainability, [w:] Modrak V., Ślusarczyk B. (eds.), The Role of Business in Achieving Sustainability. Part 2: Implication for Industry, s. 5-35, Technical University of Košice, Presov.

26. Ulbrych M. (2013), Priorytety polityki przemysłowej w Unii Europejskiej wobec wyzwań kryzysu globalnego, Prace Komisji Geografii Przemysłu Polskiego Towarzystwa Geograficznego, Kraków, s. 21-62.

27. Woś R. (2015), Kamieni kupa, czyli co się stało z polskim przemysłem, „Polityka”, nr 14(3003), s. 48-51.

28. Zintegrowana polityka przemysłowa w erze globalizacji. Konkurencyjność i zrównoważony rozwój na pierwszym planie (2010), Komunikat Komisji do Parlamentu Europejskiego, Rady, Europejskiego Komitetu Ekonomiczno-Społecznego i Komitetu Regionów, Bruksela.

\title{
THE COMPETITIVENESS SUPPORT \\ OF POLISH INDUSTRY UNDER THE NEW INDUSTRIAL POLICY ASSUMPTIONS
}

\begin{abstract}
The recently conducted public economic debates take increasingly demand to implement a new industrial policy for the economies development after the global crisis. The article takes the indicated topics, presenting the genesis of the current interest in industrial policy. The analysis of economic indicators, based on the results achieved by the European Union industry and in case individual EU countries confirms the need for the application of the new industrial policy objectives, in order to increase the competitiveness of EU industry on the global economy background.
\end{abstract}

Keywords: industrial policy, the global financial crisis, the EU industry, industry in Poland 